\title{
Prevalence of Obesity Among Thi-Qar University Students During the Year 2015- 2016
}

\author{
Dhiaa khalaf Al-aumary*, Ali Abid Saadoon AlGhuzi** \& Alaa Jassim Mohammod*** \\ * Assist professor-PhD. MBChB. Internal Medicine Department, College of Medicine, Thi- \\ Qar University, Iraq. \\ **Assist professor- PhD.MSc. MBChB. Community medicine department, college of Medicine, \\ Thi-Qar University, Iraq. \\ ***M.B.Ch.B. -Al-Sader Primary Health Care Center, Thi-Qar Health Office, Thi-Qar, Iraq. \\ *dheya.kh@utq.edu.iq ,**ali.abd.s@utq.edu.iq
}

\begin{abstract}
Background: The prevalence of overweight and obesity is increasing in both developed and developing countries. Obesity is a major risk factors for many chronic diseases including diabetes, hypertension and ischemic heart disease, so it is considering a major Public health problem.

Objectives: to study the prevalence of obesity and it is risk factors among Thi-Qar university students.

Subjects and Method: A cross sectional study had been extended from $1_{\text {st }}$ of April 2016 to $10_{\text {th }}$ of June 2016, a total of 841 students (358 of male and 456 of female) between 18 years and 36 years of age (mean $21.7 \pm 2$.3years) were selected randomly from 24 colleges of both Thi-Qar university and Mazzia college. Each participants subjected to a questionnaire that include: personal socio-demography, time of sleep per night, types of activity during leisure times, height, weight and waist circumference were measured and body mass index was calculated and used to asses' weight status. The data was analyzed by using SPSS. p value less than 0.05 was considered as statistically significant.
\end{abstract}

Result: The mean BMI was $24.17 \pm 4.0$; more than half $(59.2 \%)$ of students were of normal weight ( $63.8 \%$ of male students and $55.2 \%$ of female students ); whereas the prevalence of overweight and that of obesity among them was $28.3 \%$ and $8.1 \%$ respectively. The prevalence of obesity was nearly similar between male and female students, while the prevalence of overweight was more common among females students as compared to males (32\% of females vs. $23.1 \%$ of males).The prevalence of underweight was more common among male than female students $(5.1 \%$ of male vs. $3.7 \%$ of female $)$. Depending on their waist circumferences $3 \%$ of male and $18 \%$ of female students where at a higher risk of developing abdominal obesity co morbidities. There was significant higher prevalence of obesity and mean waist circumference with in students of more than 26 years old age and of less than 6 household family number $(\mathrm{p}<.05$ for both variables). A relatively high proportion (42.7\% for male and $35.8 \%$ for female) spend more than two hours on screen time daily. Females where significantly $(\mathrm{p}<.05)$ much less physically active than male.

Conclusion: there was high prevalence of obesity among ThiQar university students and the study supports the multi factorial etiology of obesity; it demonstrated that age, parent's education and household number are risk factors. The study also shows high prevalence of sedentary behaviors, physical inactivity among Thi-Qar university students.

Recommendation: the study results mandate the need for a Public Health strategies to 
prevent overweight and obesity and adopt a healthy dietary habit and life style.

Key word: Prevalence, Obesity, Overweight, Cross sectional study, Dietary habit, Life style. Abbreviations: WHO, World Health Organization; WC, waist circumference; BMI, body mass index; SPSS, Statistical Package for Social Sciences.

\section{Introduction:}

Obesity: is defined by WHO as a state of excess adipose tissue mass that cause health impairment (1), while overweight means increased body weight in relation to height which then compared to a stander acceptable (2).

Obesity worldwide considered as a pandemic with highly disastrous effects for human health. More than $30 \%$ of adult in USA, and more than $20 \%$ of UK are obese (with a BMI equal or more than $30 \%$ ) (3). In the last two decades the prevalence of overweight and obesity has increase three fold and the prevalence continue to rise (3).

At the beginning the increasing prevalence is started in high income countries now the increasing rates include low and middle income countries specially in urban communities. The rates of childhood obesity in developing country increased to $30 \%$ due to emerging economies (1). During the year 2015 the WHO project that around 700000 million adult aged 18 years and above were obese and 2.3 billion were overweight (4).

The four years' rate for individual to developing obesity around 5\% -7\% among non-obese women and around 7\%-9\% among non-obese man. In general, the risk for developing overweight is 1 in 2 individuals, and 1 in 4 persons to develop obesity while the risk for developing severe obesity is 1 in each 10 individual (5).

The prevalence of obesity is varied among the world being higher in United State, European countries up to $25 \%$ of both gender and Arab countries rich in oil $30 \%$ for male and
$40 \%$ for female (6). This rapid increasing involve both men and women, more in women, Hispanics, Native Americans, African Americans at a more risk of obesity, low socioeconomic status, low educational level and rural residency are a risk factors behind obesity (4).

During the year 2010, obesity and overweight causes 3.4 million death, $3.9 \%$ years of human life lost by obesity, and about $3.8 \%$ of DALYS (disability adjusted life years) worldwide (7). Obesity account for $0.7-2.8 \%$ of total health care, the obese person spent approximately $30 \%$ on medical care than normal individual (8).

According to the results of the National survey in Iraq at 2006 around $(63.6 \%$ and $69.6 \%)$ of adult males and females respectively were obese or overweight and $11 \%$ of children below 5 years of age and around $7 \%$ of school age children were either obese or overweight (10).

WHO Step wise NCD (noncommunicable disease) Risk Factor Survey at 2015 showed that the prevalence of overweight was $31.9 \%$ for adult in Iraq it was $(33.1 \%$ for male and $30.6 \%$ for females), while the prevalence of obesity was $33.5 \%$ for adult it was $(25.6 \%$ for males and $42.6 \%$ for females) (11).

The body mass index (BMI) which is equal to body weight in kilogram $(\mathrm{kg})$ divided by squared height in meter $\left(\mathrm{m}^{2}\right)$, it is one of the commonest method to classify obesity (12). The WHO considered a BIM 18.5-24.9 as normal ,25-29.9 as overweight ,3034.9 class 1 obesity, 35-39.9 class 2,40 
and more class 3 .

For further assessment in term of fat distribution through measuring waist circumference, which reflect what is called central or abdominal obesity, while the subcutaneous fat accumulation which indicate generalized obesity .The central type of obesity more common in men and associated with risk of metabolic syndrome ,type 2 diabetes mellitus and cardiovascular diseases this differences in fat distribution due to vascular anatomy, the substance that released from abdominal fat such as free fatty acid and tumor necrosis factor drains to the portal vein and as a result being in high concentration in the liver and promoted the development of diabetes mellitus.(3)

Obesity is the result of interaction of environmental factor, genetic and lifestyle. In general, it caused by a combination of high caloric dietary intake, reduce physical activity and genetic susceptibility. however, there are few cases are caused by endocrine disorder, psychiatric illness, medications, and genes (4). So it is a preventable condition through a variety of changes including personal choices and social changes. (1)

Obesity has adverse health sequences effect on both mortality and morbidity. The less mortality rates were seen among individual with BMI range 18.5-24. Framingham data collected from USA population showed that; a people at $30-42$ years old with $1 \%$ per year increased risk of death for each half kilogram increase in body weight, as the age increase the risk will be risen. As a result, the obesity will decrease the individual life expectancy by 7.1(3).

The obese and overweight individual are more prone to develop diabetes mellitus, cardiovascular disease, Dyslipidemia, musculoskeletal disorder breathing difficulty during sleep and cancer (13).

\section{Rationale of the study:}

During the last several year Iraq is financially growing, as a result high availability of food, open market, possible reason for less activity including: easily transport, increase time spent on watching television, playing computer and video games, and using social media, the university student as part of the community affected by these changes. As a result, overweight and obesity are expected to be increasingly among these age groups.

Many researches have been conducted to assess the nutritional status of children including school age group and infant but a little research to evaluate this adolescence and young adult age group as undergraduate university students, these little attentions specially nutritionally may be due to researcher believe that this group is not a vulnerable one.

This study tried to understanding the life style risk factors among university student and if there is a gender differences among students for developing a public health polices and strategies to treat and prevent the obesity. Furthermore, data from university student could be used to facilitate the implementations of nutritional programs for the population at a low cost.

\section{Objective of the study:}

This study was aimed to determine the extent of overweight and obesity among Thi-Qar university students and studying the risk factors of the problem and compare its occurrence between governmental and private colleges.

\section{Subjects and method: Design and setting:}

This study was university based cross 
sectional study carried out in college students- Thi-Qar governorate -Iraq, during the academic year $2015-2016$, from the $1^{\text {st }}$ of April $-10^{\text {th }}$ June 2016 after taken the permission of the university authority.

The population under the study included some of university students both private and governmental, both sex male and female, while the students of colleges that located ten kilometers away from Al-Nasiriya city were excluded, the students who were refused and the pregnant female student also excluded from the study.

\section{Sample size and sampling procedure:}

According to Dobson equation the sample size (n) was calculated (14) $\mathrm{n}=\mathrm{Z}^{2} \mathrm{P}(1-\mathrm{P}) / \mathrm{d}^{2}$

The level of confidence of this study was $95 \%, \mathrm{Z}$ value equal to $1.96, \mathrm{P}$ it was the prevalence of obesity in Iraq $27 \%$ from the WHO estimation (15), 0.02 is the margin of error used for this study so the sample size equal to 841 . At the time of the study the total number of student was 15100 . Nasiriya city had one governmental and one private college. Thi-Qar university had sixteen colleges and Mazaya college had eight departments. The distribution of the sample between them according to the proportion of each university.

Around $77.8 \%$ of students from ThiQar and $22.2 \%$ of students from Mazaya colleges. The sample distributed among colleges according to the proportion of each college to university. After that half of the stages from each visited colleges were chosen, finally by simple random sampling according to the student sitting position the selected numbers were chosen.

\section{Questionnaire:}

For the purpose of the study a specific questionnaire designed were prepared and opinion of two experts was taken, so some modification was done to the original one by changing several item. The questionnaire was divided to three part including socio demographic, dietary habit and physical activity, and it including information about, age, sex, number of household, monthly family income, level of parent education, residency, time of sleeping per night, type of activity during leisure time, dietary. Weight, height and WC were measured for each student.

the questionnaire was pretested on fifty students of Nursing college, Data collection were performed in two stages, firstly a questionnaire selfreported and secondly anthropometric measure.

After interviewing the students, the purpose of the study was explained; questionnaire was clarified and the idea behind taking the anthropometric measure also was explained. The students were informed that, they were free in their participation in the study. The importance about honest in their response also was discussed and informed verbal consent were taken. Finally, the collected data were revised at the end of the day about completeness.

\section{Anthropometric measures:}

Weight measurement was taken to the nearest $0.1 \mathrm{~kg}$ by using digital weight scale for all participants with a well calibration while the student wearing a light clothes with an accepted error of $0.1 \mathrm{~kg}$, the balance of scale was checked at frequent interval for adequacy. Height measurements was performed by using portable height measure to the nearest $0.5 \mathrm{~cm}$, the student stood with foot together, head in a horizontal way and without 
shoes.

Waist circumference measurement was performed by using a flexible and not stretchable tape measure placed horizontally around the abdomen at the midpoint between the iliac crest and lower rib at the end of normal expiration as seen from anterior view to the nearest $0.5 \mathrm{~cm}$.

Statistical Analysis

The collected data were coded and analyzed using Statistical Package for Social Sciences version 23.

The analysis data results were expressed in form of percentage, means and stander deviation (SD). Both T- test and ANOVA were used to compare between means.

The chi- Squared test was calculated to find the relationship between variables.

\begin{abstract}
All calculate $\mathrm{p}$ values were made on 2sided test and at 5\% (0.05) level of confidence. To evaluate obesity, BMI was calculated by using the stander formula (16):

$\mathrm{BMI}=$ weight $(\mathrm{kg}) /$ height $(\mathrm{m})^{2}$

According to the WHO and International Task Force, the weight status classified into four categories: (underweight with BMI $<18.5$, normal weight with BMI $=18.5-24.9$, overweight with BMI 25-29.9 and obese with $\mathrm{BMI} \geq 30$ ). Iraqi population didn't have any cut off point criteria for waist circumference as an indicator of co morbidities risk, the stander adopted by WHO were used by the present study to evaluate the risk; so WC of $>88 \mathrm{~cm}$ for female and WC of $>102$ for male were consider as indicator of risk factors (3).
\end{abstract}

\section{Result:}

Table (2): show the general and demographic characteristics of the participants, the study included 841 students with $100 \%$ response rate,385 (45.8\%) males, while 456 (54.2 $\%$ )were females. Around $90 \%$ of them of urban resident, Majority of them $76.6 \%$ with $\leq$ 1000000 ID monthly per capita income. More than half $58.6 \%$ lived in families range between 6 and 10 members. Majority of students $85.2 \%$ from medium social class.

Table ( 3 ) show the mean age of studied sample which was $21.7 \pm 2.1$ years ;it was 22.6 \pm 2.5 years for male ;20.9 \pm 1.7 years for female .The mean weight of participant was $65.319 \pm 12.34 \mathrm{~kg} ;$ It was $70.43 \pm 12.68 \mathrm{~kg}$ for male $; 60.9 \pm 10.34 \mathrm{~kg}$ for female .The mean height was $164.33 \pm 9.32 \mathrm{~cm}$; it was $172.41 \pm 5.81 \mathrm{~cm}$ for male and $157.50 \pm 5.48$ $\mathrm{cm}$.The mean weight and height were higher in male as compared to female students with a statistically differences between two sex $(\mathrm{p}=.0001$ for both height and weight $)$.

The mean waist circumference was $80.53 \pm 9.2 \mathrm{~cm}$ and the mean BMI was $24.17 \pm 4.00$ $\mathrm{kg} / \mathrm{m}$. There was a significance differences in the mean BMI and waist circumferences between two gender, $\mathrm{p}$ value was 0.001 and 0.002 respectively.

Table (4) There were a significance differences between both sex regarding reading and sport activities, male students engaged more in sport and reading activity. There were no differences regarding time spent on watching TV and using computer and net.

The means of sleep hours per night for the studied sample were7.6 \pm 1.4 hours, without 
significant differences between both of them. Around $75.9 \%$ of them taking a nap versus $24.1 \%$ being not taking a nap. The prevalence of overweight and obesity over all the studied subjects was $36.4 \%$ (28\% were overweight ,8.1 were obese) and minority $4.4 \%$ were underweight, and majority of students $59.2 \%$ with a normal weight. (figure 1 ).

The prevalence of obesity nearly similar for male and female $(7.7 \%$ of male, and $8.3 \%$ of female), while the prevalence of overweight was more common among female $(23.1 \%$ of males and $32.6 \%$ of female) and there were significant association between BMI and sex. It was observed that the prevalence of overweight and obesity was increased among students of private as compared to public university, and the association between them statistically significance $(\mathrm{p}=0.0001)$. (figure 2$)$

It was seen that, a consistent increase in the prevalence of overweight and obesity with increasing age and the association between age and BMI class was statistically significance $(\mathrm{p}=.026)$.

The prevalence of overweight and obesity increased with decrease in the family member, the student from a family with less than 6 member showed higher prevalence rate of overweight and obesity, a negative association was seen and it was statistically significant $(\mathrm{p}=.035)$.

It was observed that the prevalence of overweight and obesity was increased with increased parent education and the association between them statistically significant ( $\mathrm{p}=$ .014 for father education and $\mathrm{p}=0.001$ for mother education).

There were no significant association between the prevalence of overweight /obesity and each of the following: monthly family income $(\mathrm{p}=.497)$, nutritional status of parent $(\mathrm{p}=.064)$, socioeconomic status $(\mathrm{p}=.507)$, residency $(\mathrm{p}=.182)$, and history of smoking $(\mathrm{p}=.273)$.

Also there no significant association with sleep hours at night and day time sleep.

There were significant association between mean WC and sex, age and No. of family member. Mean WC being higher among female students, it was increasing with increased age and higher among students belong to the family with $\leq 5$ member.

Depending on WC $3 \%$ of male and $18 \%$ of female at a risk of abdominal obesity co morbidity.

Table 1: It shows the Prevalence of Obesity in some Eastern Mediterranean countries.

\begin{tabular}{|c|c|c|}
\hline Country & Male & Female \\
\hline Jordon & $19.6 \%$ & $37.9 \%$ \\
\hline Kuwait & $29.6 \%$ & $55.2 \%$ \\
\hline Saudi Arabia & $23 \%$ & $36.4 \%$ \\
\hline Syria & $12.4 \%$ & $24.5 \%$ \\
\hline Iran & 29.5 & 25.6 \\
\hline
\end{tabular}


Thi-Qar Medical Journal (TQMJ): Vol.(12), No.(2), 2016

Email:utjmed@utq.edu.iq

Web Site: https://jmed.utq.edu.iq

Table 2 : Socio-Demography of the studied Students.

\begin{tabular}{|c|c|c|}
\hline Variable & $\mathbf{N}$ & $\%$ \\
\hline \multicolumn{3}{|l|}{ Sex } \\
\hline Male & 385 & 45.9 \\
\hline Female & 456 & 54.2 \\
\hline \multicolumn{3}{|l|}{ Residency } \\
\hline Urban & 756 & 89.8 \\
\hline Rural & 85 & 10.1 \\
\hline \multicolumn{3}{|l|}{ Households } \\
\hline$<6$ & 252 & 29.2 \\
\hline $6-10$ & 493 & 58.8 \\
\hline $10+$ & 96 & 11.4 \\
\hline \multicolumn{3}{|l|}{ Per capita monthly income } \\
\hline$\leq 1000000$ ID & 644 & 76.6 \\
\hline$>1000000 \mathrm{ID}$ & 197 & 23.4 \\
\hline \multicolumn{3}{|l|}{ Socioeconomic status } \\
\hline Low & 54 & 6.4 \\
\hline Medium & 717 & 85.2 \\
\hline High & 70 & 8.3 \\
\hline \multicolumn{3}{|l|}{ Family history of obesity } \\
\hline Yes & 289 & 31 \\
\hline No & 579 & 69 \\
\hline
\end{tabular}

Table (3): Distribution of the Weight Parameter according to Sex.

\begin{tabular}{|c|c|c|c|}
\hline Parameter & Total & Male & Female \\
\hline Age(years)mean \pm SD & $21.7 \pm 2.3$ & $22.6 \pm 2.5$ & $20.9 \pm 1.7$ \\
\hline WT(kg) mean \pm SD & $65.316 \pm 12.34$ & $70.43 \pm 12.68$ & $60.9 \pm 10.34$ \\
\hline HT $(\mathrm{cm})$ mean $\pm \mathrm{SD}$ & $164.33 \pm 9.32$ & $172.41 \pm 5.81$ & $157.51 \pm 5.5$ \\
\hline $\mathrm{WC}(\mathrm{cm})$ mean $\pm \mathrm{SD}$ & $80.53 \pm 9.2$ & $79.47 \pm 10.08$ & $81.43 \pm 8.47$ \\
\hline BMI $(\mathrm{kg} / \mathrm{m})$ mean \pm SD & $24.17 \pm 4.00$ & $23.69 \pm 4.05$ & $24.57 \pm 3.9$ \\
\hline
\end{tabular}


Thi-Qar Medical Journal (TQMJ): Vol.(12), No.(2), 2016

Email:utjmed@utq.edu.iq

Web Site: https://jmed.utq.edu.iq

Table (4): Show Time per hour of Different Activity according to Sex.

\begin{tabular}{|c|c|c|c|c|}
\hline $\begin{array}{l}\text { Type of } \\
\text { activity }\end{array}$ & Time /hours & $\begin{array}{l}\text { Male } \\
\text { No. \% }\end{array}$ & $\begin{array}{l}\text { Female } \\
\text { No. } \%\end{array}$ & $P$ value \\
\hline \multirow[t]{3}{*}{ Reading } & No activity & $309(80.3)$ & $393(86.2)$ & .012 \\
\hline & $<1$ hour & $9(2.3)$ & $2(0.4)$ & \\
\hline & 1 hour & $67(17.4)$ & $61(13.4)$ & \\
\hline \multirow{6}{*}{$\begin{array}{c}\text { Watching } \\
\text { TV }\end{array}$} & No activity & $191(49.6)$ & $203(44.5)$ & .197 \\
\hline & $<1$ hour & $12(3.1)$ & $9(2.0)$ & \\
\hline & 1-2 hours & $135(35.1)$ & $179(38.6)$ & \\
\hline & 3-4 hours & $36(9.9)$ & $57(12.5)$ & \\
\hline & 5-6 hours & $7(1.8)$ & $10(2.2)$ & \\
\hline & $>6$ hours & $4(1.0)$ & $1(0.2)$ & \\
\hline \multirow[t]{6}{*}{ Internet } & No activity & $83(21.6)$ & $133(29.2)$ & .184 \\
\hline & $<1$ hour & $7(1.8)$ & $10(2.2)$ & \\
\hline & 1-2 hours & $131(34.0)$ & $150(32.9)$ & \\
\hline & 3-4 hours & $98(25.5)$ & $96(21.1)$ & \\
\hline & 5-6 hours & $45(11.7)$ & $47(10.3)$ & \\
\hline & $>6$ hours & $21(5.5)$ & $20(4.4)$ & \\
\hline \multirow[t]{4}{*}{ Sport } & No activity & $200(51)$ & $366(80.3)$ & .0001 \\
\hline & $<30$ minutes & $1(0.3)$ & $12(2.6)$ & \\
\hline & $\begin{array}{c}30 \text { minutes-1 } \\
\text { hour }\end{array}$ & $82(21.3)$ & $59(12.9)$ & \\
\hline & $>1$ hour & $102(26.5)$ & $19(4.2)$ & \\
\hline
\end{tabular}

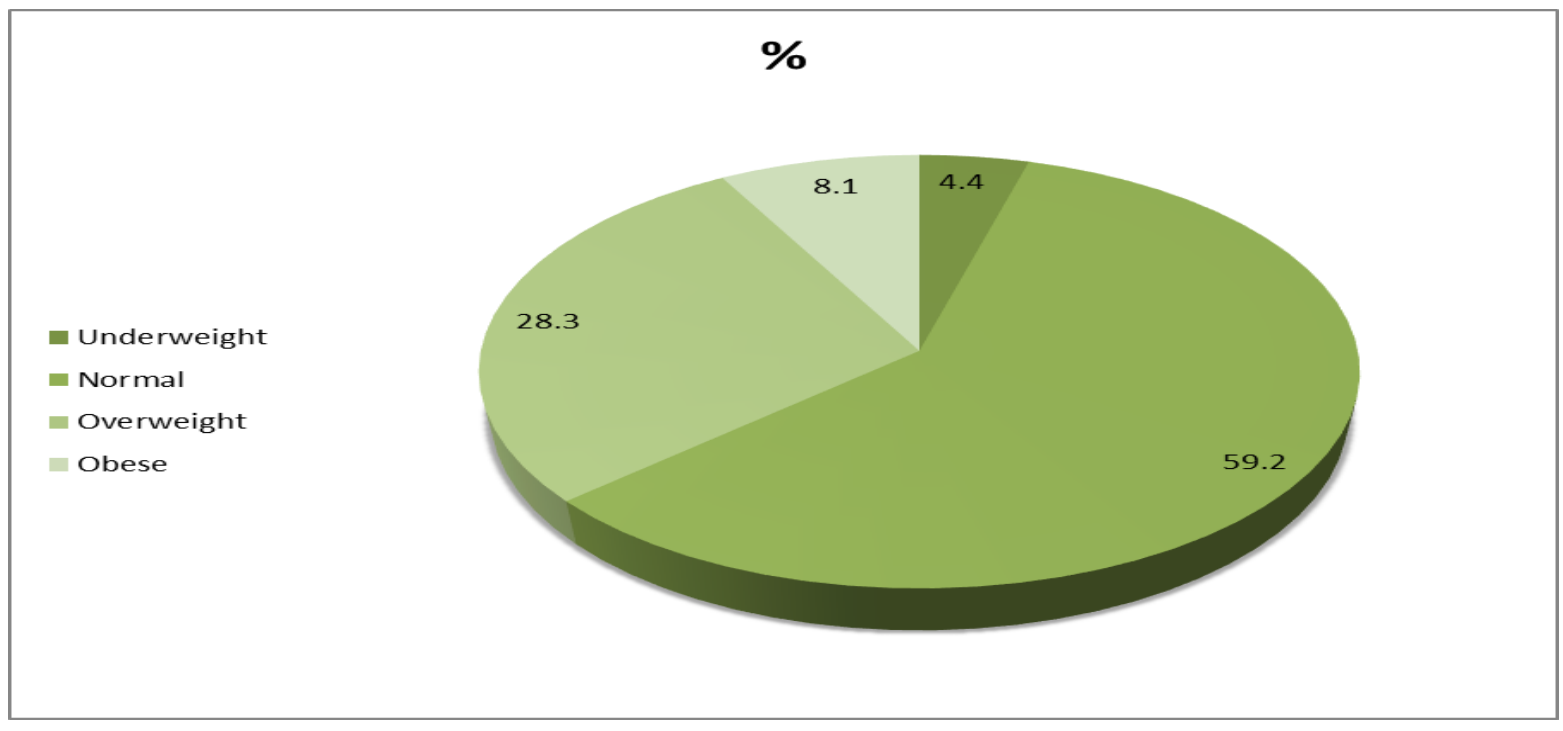

Figure (1): Prevalence of overweight and obesity among public and private university in 
Thi-Qar province.



Figure (2): Prevalence of obesity according to the type of university

\section{Discussion:}

The purpose of present study was to determine the prevalence of obesity and it is risk factors among university students in Thi-Qar province. Accordingly, the BMI was calculated to assess the weight status of studied sample, and the result indicate that more than half $59.2 \%$ of participant were of a normal weight and the normal BMI was more common among male students $63.8 \%$ as compared to $55.2 \%$ of female. Compared to other studies , $65.0 \%$ of Karbala university students (17), and $67.7 \%$ of the Tai Solarin university of education in Nigeria (18). The king Saud university students had only $45.8 \%$ of students with normal BMI in Saudi Arabia (19).

The prevalence of obesity was $8.1 \%$ nearly similar between two gender $(7.7 \%$ for male and $8.3 \%$ for female) while the prevalence of overweight was more common among female students $32.6 \%$ as compared to male students $23.1 \%$.
The prevalence of underweight was different between male and female $(5.1 \%$

for male, and $3.7 \%$ for female).

The finding of this study regarding the prevalence of obesity was lower than the prevalence $32 \%$ which concluded by WHO for the Iraqi population during the year 2005 (20) and less than the prevalence $23.8 \%$ concluded by Mansour et al., in Basrha (21). It was more than the prevalence of obesity among Karbala university students $5.6 \%(17)$ and $2.9 \%$ among university student in china (22). And it was approximate to the prevalence of obesity $8.9 \%$ among Kuwait University students (23).

In a studies conducted among King Saud university students in Saudi Arabia the prevalence of overweight and obesity that concluded were higher $31 \% \quad \& 23 \%$ respectively (19). The prevalence of overweight $28.5 \%$ among university students in Jordon nearly similar to present study (24). 
Al - Hilaly et al.,2008 concluded that $29.3 \%$ of adult population in Karbala were obese and the mean BMI and WC were $(25.2 \pm 2.2 \mathrm{~kg} / \mathrm{m}) \&(82.65 \pm 8.7 \mathrm{~cm})$ respectively (25).

Data collected by the WHO for adult population show that the mean BMI for male was24.1 and for female was 25.2(19), the result of this study also show that the mean BMI of male is less than the BMI of female but both means of BMI were less than the WHO data. This result may have related to the younger age of university students.

There were significant differences in the in the mean BMI between two gender $(\mathrm{p}=.001)$.

The mean waist circumferences were significantly higher in the female than the male $(\mathrm{p}=.002)$, with $18 \%$ of female at a risk of developing abdominal obesity co morbidities as compared to $3 \%$ of some male students with increased risk. There was lower range of $\mathrm{WC}$ at the age group $18-20$ years which was the early period in the university.

As compared to other studies, Al -Hilaly concluded higher prevalence of abdominal obesity among women $51.5 \%$ while it was $13.3 \%$ among men (25) also the result of the present study consistent with other studies in USA (26), Iran (27) and Turkey (28).

Less than 6 family member was significantly associated with increased in waist circumference $(p<.05)$ this indicate to directed a healthy nutritional program and education towards these families as a preventive strategy. Al-Qauhiz study found that obesity was less among large household number (29). There were no significant association between $\mathrm{WC}$ and monthly income, residency of urban versus rural. These results consistent with Al-Gahbban study (17), however; it was different from other study by Sulieman who showed that low family income one of the risk factors behind obesity (24).

Some studies concluded that female sex was one of the risk factor behind obesity with a higher prevalence than male (24), other studies revealed that male have a higher prevalence rate of obesity (30).

The present sample showed that the prevalence of obesity was nearly similar between two gender. It has been concluded that the prevalence of obesity and overweight was increase with increasing age (31). This give idea that obesity and overweight is a progressing problem that once happened, tend to increase with time, the present study revealed that the prevalence of overweight and obesity increase with increasing age.

Regarding the socioeconomic status, it has been suggested that inversely related to prevalence of obesity $(32,33)$ and it has been found that parent with lower educational level was associated with a greater risk of overweight and obesity (34). Furthermore, high family incomes are inversely related to the BMI in developed country while in developing country it was directly proportionate to BMI $(34,35)$. Person from low family income has been found with high caloric intake.

The present study shows consistent increase in the prevalence of overweight and obesity with increase parent education, a result which is consistent with the results of Basrha study (36) and Nabuls study (37).

With respect to socioeconomic status and family income, the present study found that there was no association with obesity. These result are in consistent with the results of Karbala study (17)and Nablus (37)which found that, there was no significant differences in the mean BMI among students from some families with different income.

It has been suggested that family history of obesity and residency are a risk factors behind obesity. The present study demonstrated that no significant association between nutritional status of parents and prevalence of obesity and overweight in a studied sample, while the Saudi study found that family history of 
obesity has significant association with the prevalence of obesity (29).

Also the present study concluded that no significance association between residency and prevalence of obesity and this result was in consistent with result of other study in Iraq (17). From this study , I observed that ,sedentary life was more common among university students, more than third $(40 \%)$ of student $(42.7 \%$ of male and $35.8 \%$ of female) spend more than two hours /day using computer games ,social media and internet and only $32 \%$ (48\% of male and $19 \%$ of male ) engaged in sport activity with a statistically gender differences $(\mathrm{p}=$.0001) this gender differences could be attributed to cultural reasons where females have limited facilities and opportunities for physical activity. This differences was found in many studies, Salameh et al., found that male students had significant higher level of physical activity during their leisure time as compared to female student in Lebanon university (38). It has been reported among United Kingdome population that a relatively higher proportion of males as compared to female was active at every ages (39). A recent study on university students demonstrated that around a half of participant exercised 30 minutes to an hour a day (40).

Limitations of the study:

1.the collection of data based on the selfreported questionnaire which result in over or under estimation of the variables, so information bias cannot be excluded.

2.regarding the assessment of physical activity I don't asses the exact energy expenditure from physical activity.

3. the family history of obesity is a subjective and not reflects the real risk of obesity in the family, and it is a better if we ask about the anthropometric measures of the parents but majority of the students don't know these measures.

\section{Conclusion:}

It can be concluded from the present study that:
1. The prevalence of obesity and overweight were lower than obesity and overweight reported among the university students of the neighborhood countries.

2. The present study supports the multifactorial etiology of obesity, it demonstrated that age, parent education and household member are a risk factors.

3. Around $40 \%$ of male and female students spend more than two hours on sedentary life.

4. This study generated information which can be used as a basis for planning strategies to prevent obesity and overweight.

5. Understanding the differences between two gender regarding the life style related risk factors among students is important for public health policies to treat and prevent obesity.

\section{Recommendation:}

There is a need for a Public Health strategies to prevent overweight obesity, started from preschool extended to the university and to the entire community. Improving students' knowledge about healthy eating habit and nutrition will promote healthy body weight and reduce the prevalence of obesity and overweight.

Nutritional information and education should be included through the curriculum of all educational stage.

\section{References:}

1. Obesity and overweight [Internet]. World Health Organization. 2016 [cited 28 September 2016]. A available from: http://www.who.int/mediacentre/factsheets /fs311/en/

2. Levi J, Segal L, Rayburn J, Martín A. State of Obesity: BETTER POLICIES FOR A HEALTHIER AMERICA [Internet]. 1st ed. Robert Wood Johnson Foundation; 2015 [cited 28 September 2016]. Available from: http://stateofobesity.org/files/stateofobesit 
y2015.pdf

3. Boon $\mathrm{N}$, Davidson $\mathrm{S}$, Colledge $\mathrm{N}$, Walker B, Hunter J, Ralston S. Davidson's principles \& practice of medicine. 22nd ed. Edinburgh: Elsevier/Churchill Livingstone; 2014.

4. Rakel Rakel D. Textbook of Family Medicine, Ninth Edition. 9th ed. Elsevier; 2016.

5. Hu F. Obesity epidemiology. Oxford: Oxford University Press; 2008.

6. Ginter ESimko V. Adult obesity at the beginning of the $21 \mathrm{st}$ century: epidemiology, pathophysiology and health risk. - PubMed - NCBI [Internet]. Ncbi.nlm.nih.gov. 2008 [cited 28 September 2016]. Available from: http://www.ncbi.nlm.nih.gov/pubmed/186 30807

7. Fleming $\mathrm{T}$, Robinson $\mathrm{M}$, Thomson $\mathrm{B}$, Graetz N, Margono C, Marie N. Global, regional, and national prevalence of overweight and obesity in children and adults during 1980-2013: a systematic analysis for the Global Burden of Disease Study 2013 [Internet]. Thelancet.com. 2014 [cited 28 September 2016]. Available from: http://www.thelancet.com/journals/lancet/ article/PIIS0140-6736(14)60460-

8/abstract

8. Withrow DAlter D. The economic burden of obesity worldwide: a systematic review of the direct costs of obesity. Obesity Reviews. 2011;12(2):131-141.

9. World Health Organization WHO, Global InfoBase, international comparison. Available at: https://apps.who.int/infobase/Comparis ons.aspx.

10. ManageMent of overweight/obesity for Primary Health Care workers [Internet]. 1st ed. United States Agency for International Development; 2013 [cited 4 October 2016]. Available from: http://phd.iq/LionImages/PDFStore/Manag ement\%20of\%20Obesity\%20and\%20Over weight $\% 20 \mathrm{Jan} 17$. docxSA.pdf

11.WHO. step wise non communicable disease risk factors survey at 2015 .

12. TOOL E3 Measurement and assessment of overweight and obesity ADUL TS [Internet]. 1st ed. 2008 [cited 28 September 2016]. Available from: http://www.fph.org.uk/uploads/HealthyWe ight_SectE_Toolkit03.pdf

13. Kasper D, Fauci A, Hauser S, Longo

D, Jameson J, Loscalzo J. Harrison's principles of internal medicine. 19th ed. New York: McGraw-Hill Education; 2015.

14. Dobson A J, Gebski V J. Sample sizes for comparing two independent proportions using the continuity- corrected arc sine transformation. The Statistician. 1986; 35, 51-53.

15. The World Factbook - Central Intelligence Agency [Internet]. Cia.gov. 2016 [cited 4 October 2016]. Available from:

https://www.cia.gov/library/publications/t he-world-

factbook/rankorder/2228rank.html

16. World Health Organization. BMI classification.

Available http://apps.who.int/bmi/index.jsp?intro Page=intro_3.html.

17. Al-Ghabban S. Prevalence of 
Overweight and Obesity among Students in University of Kerbala. University of Babylon - Medical Journal of Babylon [Internet]. 2014 [cited 4 October 2016]; Available from: http://www.medicaljb.com/article.aspx?jri $\mathrm{d}=73$

18. Olusanya JOmotayo O. Prevalence of Obesity among Undergraduate Students of Tai Solarin University of Education, Ijagun, Ijebu-Ode [Internet]. 1st ed. Pakistan Journal of Nutrition; 2011 [cited 29 September 2016]. Available from: http://citeseerx.ist.psu.edu/viewdoc/downl oad?doi=10.1.1.472.8292\&rep=rep1\&type $=$ pdf

19. Al Turki YA. Overweight and Obesity among university students, Riyadh, Saudi Arabia. Middle East Journal of Family Medicine; 2007; 5(2). Available at: http://www.mejfm.com/journal/March200 7/Overweight.htm.

20.WHO Step Wise Non Communicable disease risk factor survey 2005.

21. Mansour A, Al-Maliky A, Salih M. Population Overweight and Obesity Trends of Eight Years in Basrah, Iraq. Epidemiology: Open Access. 2012;02(01).

22. Sakamaki R, Toyama K, Amamoto R, Liu C, Shinfuku N. Nutritional knowledge, food habits and health attitude of Chinese university students -a cross sectional study-. Nutrition Journal. 2005;4(1).

23. Al-Isa AN. Obesity among Kuwait University students: an explorative study. PubMed - NCBI [Internet]. Ncbi.nlm.nih.gov. 2016 [cited 30 September 2016]. Available from: https://www.ncbi.nlm.nih.gov/pubmed/10

\section{2}

24. Salman MAjeel N. 103 Iraqi J. Comm. Med., Apr. 2013 (2) Prevalence of Overweight and Obesity among Public Primary School Children in Basrah City [Internet]. 1st ed. Iraqi J. Comm. Med; 2013 [cited 30 September 2016]. Available from: http://basmedcol.edu.iq/media/2014/01/Pr evalence-of-obesity-among-schoolchildren-in-Basrah.pdf

25. Al-Hilaly K, Aboud H, Al-Ghabban S. Prevalence of Obesity among Adult Population in Karbala [Internet]. 1st ed. Kufa Med. Journal; 2008 [cited 30 September 2016]. Available from: http://www.iasj.net/iasj?func=fulltext\&aId $=52493$

26. Janssen I, Katzmarzyk P, Ross R. Body mass index, waist circumference, and health risk: evidence in support of current National Institutes of Health guidelines. - PubMed - NCBI [Internet]. Ncbi.nlm.nih.gov. 2002 [cited 30 September 2016]. Available from: https://www.ncbi.nlm.nih.gov/pubmed/12 374515

27. Azadbakht L, Mirmiran P, Shiva N, Azizi F. General Obesity and Central Adiposity in a Representative Sample of Tehranian Adults: Prevalence and Determinants. International Journal for Vitamin and Nutrition Research. 2005;75(4):297-304.

28. Akbay E, Buğdaycı R, Tezcan $\mathrm{H}$, Konca K, Yazar A, Pata C. The Prevalence of Obesity in Adult Population in a City on the Mediterranean Coast of Turkey [Internet]. 1st ed. Turkish Journal of Endocrinology and Metabolism, 2003 
[cited 30 September 2016]. Available from:

http://cms.galenos.com.tr/FileIssue/8/180/ article/31-35.pdf

29. Al Qauhiz N. Obesity among Saudi Female University Students: Dietary Habits and Health Behaviors. - PubMed NCBI [Internet]. Ncbi.nlm.nih.gov. 2010 [cited 30 September 2016]. Available from:

https://www.ncbi.nlm.nih.gov/pubmed/21 073847

30. Cuong T, Dibley M, Bowe S, Hanh T, Loan T. Obesity in adults: an emerging problem in urban areas of Ho Chi Minh City, Vietnam. European Journal of Clinical Nutrition. 2007.

31. Magarey A, Daniels L, Boulton T, Cockington R. Predicting obesity in early adulthood from childhood and parental obesity. International Journal of Obesity. 2003;27(4):505-513.

32. Mozaffari HNabaei B. Obesity and Related Risk Factors [Internet]. 1st ed. Indian Journal of Pediatrics; 2007 [cited 30 September 2016]. Available from: http://medind.nic.in/icb/t07/i3/icbt07i3p26 5.pdf

33. Reidpath D, Garrard J, Mahoney M, Townsend M, Burns C. An ecological study of the relationship between social and environmental determinants of obesity. - PubMed - NCBI [Internet]. Ncbi.nlm.nih.gov. 2002 [cited 30 September 2016]. Available from: https://www.ncbi.nlm.nih.gov/pubmed/11 943585

34. WHO | Obesity: preventing and managing the global epidemic [Internet].
Who.int. 2003 [cited 30 September 2016]. Available

from: http://www.who.int/nutrition/publications/ obesity/WHO_TRS_894/en/

35. Wang YBeydoun M. The Obesity Epidemic in the United States Gender, Age, Socioeconomic, Racial/Ethnic, and Geographic Characteristics: A Systematic Review and Meta-Regression Analysis. Epidemiologic Reviews. 2007;29(1):6-28.

36. Salman MAjeel N. 103 Iraqi J. Comm. Med., Apr. 2013 (2) Prevalence of Overweight and Obesity among Public Primary School Children in Basrah City [Internet]. 1st ed. Iraqi J. Comm. Med; 2013 [cited 30 September 2016]. Available from: http://basmedcol.edu.iq/media/2014/01/Pr evalence-of-obesity-among-schoolchildren-in-Basrah.pdf

37. Isbaih M. Prevalence of Overweight and Obesity among School-Age Childr en in Nablus City [Internet]. 1st ed. An-Najah Nation al University; 2009 [cited 30 September 2016]. Available from: https://scholar.najah.edu/sites/default/files/ all-

thesis/prevalence_of_overweight_and_obe sity_among_school_age_children_6-

12_grade_in_nablus_city.pdf

38. Salameh P, Jomaa L, Issa C, Farhat G, Salam $\tilde{A} \subset$ J, Zeidan N Et al. Assessment of Dietary Intake Patterns and Their Correlates among University Students in Lebanon. Frontiers in Public Health. 2014;2.

39. Department of Health, Physical Activity, Health Improvement and Protection; 2011 Start Active, Stay Active: A report on physical activity from the four 
Thi-Qar Medical Journal (TQMJ): Vol.(12), No.(2), 2016

home countries' Chief Medical Officers

[Internet]. 1st ed. [cited 30 September 2016].

Available from:

https://www.gov.uk/government/uploads/ system/uploads/attachment_data/file/2163 70/dh_128210.
40. Hill M, Sweeney S, Clinton-Scott B. Lifestyle Behaviors among Students at a Historically Black University. Undergraduate Research Journal for the Human Sciences [Internet]. 2015 [cited 30 September 2016];14(1). Available from: http://www.kon.org/urc/v14/hill.html 


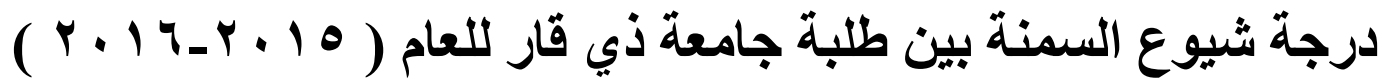

الاع جاسم محمثي

علي عبا سعدون الغزي

ضياء خلف مران العمري

الخلاصة :

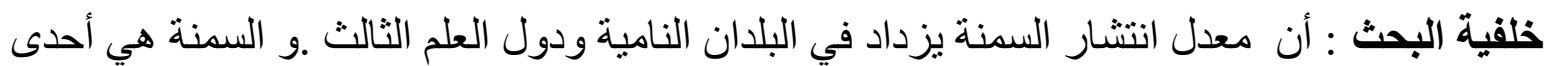

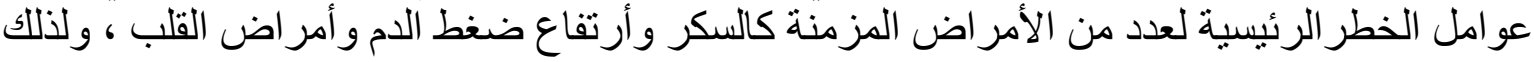

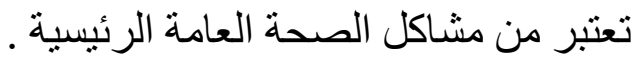

الهدف : در اسة معدل انتنار السمنة و العو امل المرتبطة بها بين طلبة الجامعات في محافظة ذي قار.

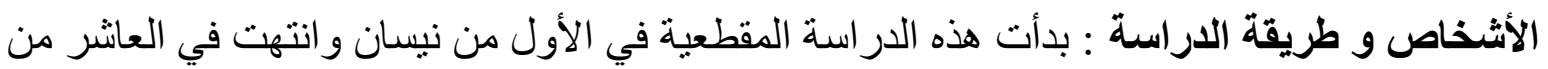

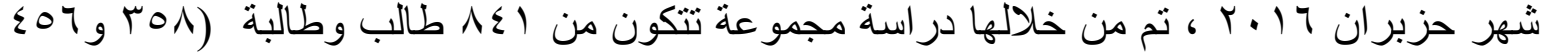

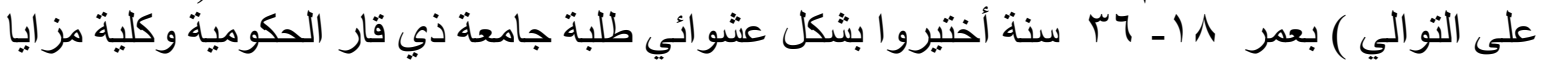

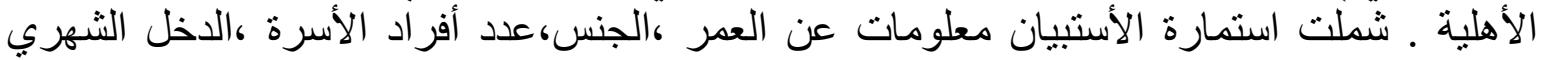

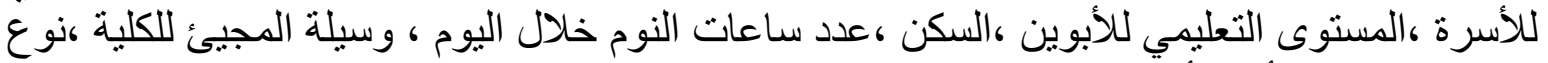

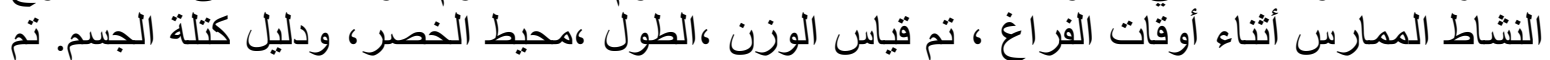

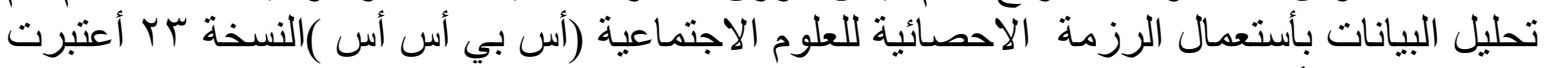

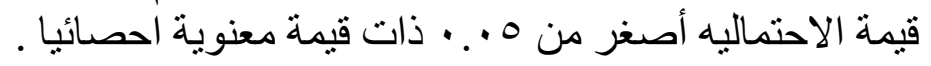

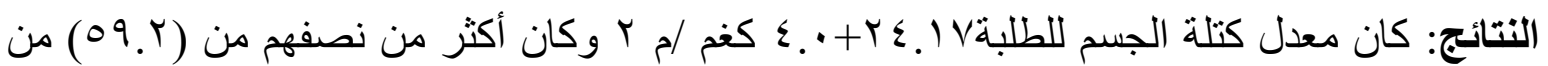

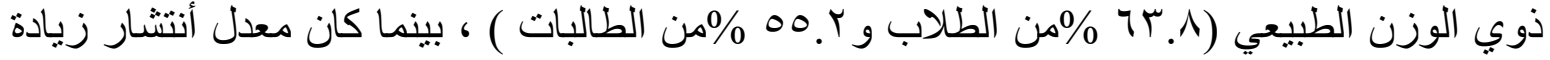

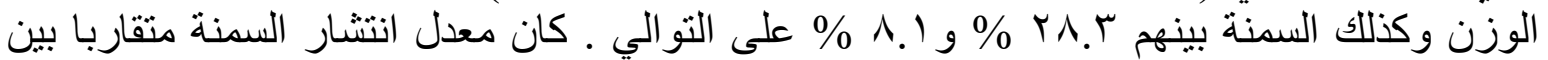

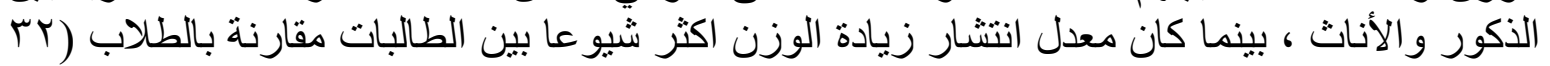

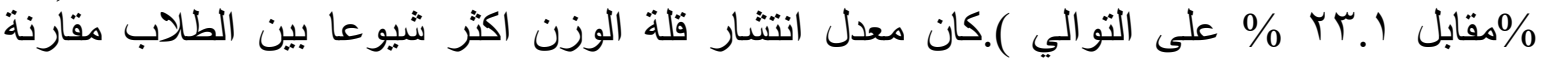

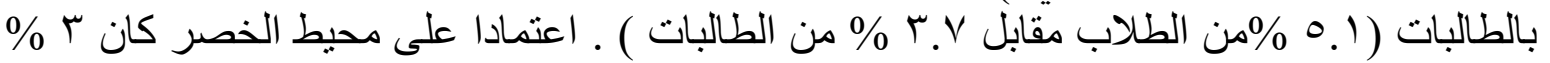

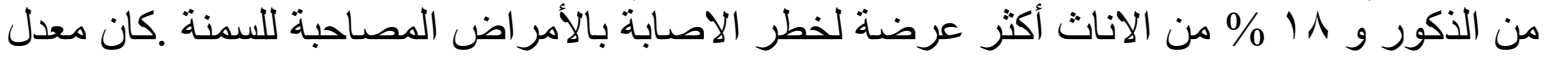

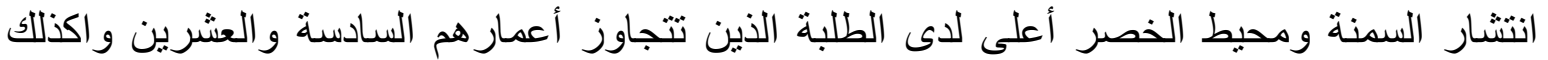

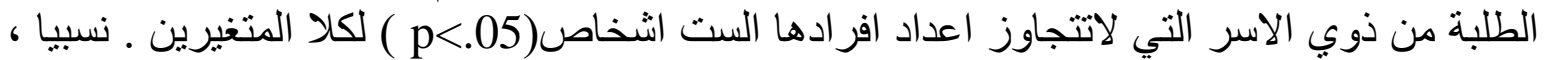

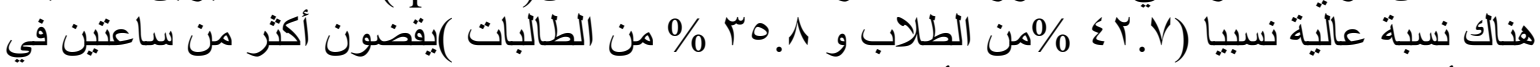

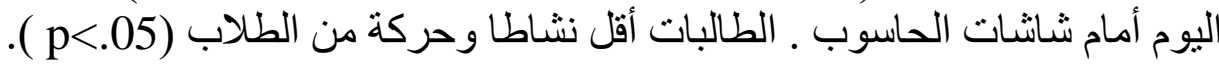

الاستنتاجات : هناك نسبه عاليه من السمنه بين طلبة جامعة ذي قار وايضا تدعم هذه الدر اسة بأنه

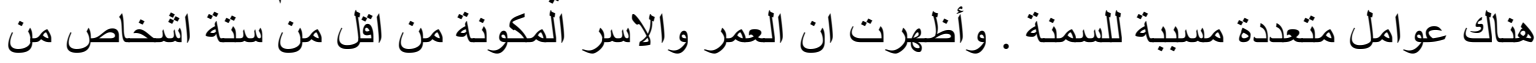

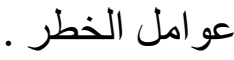


Thi-Qar Medical Journal (TQMJ): Vol.(12), No.(2), 2016

Email:utjmed@utq.edu.iq

Web Site: https://jmed.utq.edu.iq 